\title{
Effect of Temperature Downshifts on Performance and Microbial Community Structure on Pilot-Scale Sequencing Batch Biofilm Reactors Treating Hypersaline Wastewater
}

\author{
Shihu Liu*(**) Ziyuan Lin*, Jiong Zhou*, Yongsheng Zhang*, Jiale Wang*and Jian Zhou*† \\ *Key Laboratory of the Three Gorges Reservoir's Eco-Environments, Chongqing University, Chongqing, 400045, \\ P.R. China \\ **Chongqing Drainage Co. Ltd, Chongqing, 400045, P. R. China \\ $\dagger$ Corresponding author: Jian Zhou; 15523829081@126.com
}

Nat. Env. \& Poll. Tech.

Website: www.neptjournal.com

Received: 16-01-2020

Revised: $11-03-2020$

Accepted: 16-04-2020

Key Words:

Pilot-scale SBBR;

Hypersaline wastewater;

PCR-DGGE;

Bacterial community

\begin{abstract}
Low temperature and high salinity can strongly inhibit metabolic activities of the microbial population, resulting in low efficiency of biological wastewater treatment. Using $70 \mathrm{~g} . \mathrm{L}^{-1} \mathrm{NaCl}$ pickle mustard wastewater as influent, three pilot-scale sequencing batch biofilm reactors (SBBRs), subjected to temperature downshifts and fluctuation ranging from $30 \pm 4^{\circ} \mathrm{C}$ to $10 \pm 4{ }^{\circ} \mathrm{C}$, were conducted over 200 days. Polymerase Chain Reaction-Denaturing Gradient Gel Electrophoresis (PCR-DGGE) was used to reveal the microbial community structure succession in reactors. Results showed that when the temperature was $10 \pm 4^{\circ} \mathrm{C}$, the COD removal efficiencies of SBBRs $\left(1,2\right.$ and $3 \mathrm{~kg} \mathrm{COD} \mathrm{m}^{-3} \mathrm{~d}^{-1}$ organic loading rate), were $91.6 \%(\sigma=\cdot, \wedge \vee), 87.84 \%(\sigma=\cdot, 9 \mathrm{r})$ and $83.34 \%(\sigma=\cdot, \wedge \circ)$, respectively. Compared with the average removal efficiencies when the reactors operated at $30 \pm 4^{\circ} \mathrm{C}$, the efficiency reductions of 1,2 and $3 \mathrm{~kg} \mathrm{COD} \mathrm{m}^{-3} \mathrm{~d}^{-1}$ reactors were $4.47 \%, 4.58 \%$ and $4.57 \%$. As the temperature decreased, microbial population diversity did not change remarkably. However, the microbial structure changed significantly, bacteria which had strong adhesion and a wide growth temperature range were competitive. At low temperature, the predominant species were Thalassolituus oleivorans, Halotalea alkalilenta and Kangiella koreensis, which were all related to pollutant-degrading halophilic bacteria.
\end{abstract}

\section{INTRODUCTION}

Hypersaline wastewater is defined as a kind of wastewater containing more than 35 g. $\mathrm{L}^{-1}$ total dissolved solids, mainly generated by industries such as petroleum, printing and pesticide industry. Treatment of saline wastewater represents approximately $5 \%$ of the worldwide wastewater treatment requirements (Lefebvre et al. 2007). Generally, these types of wastewaters contain a high concentration of organic matter and toxic pollutants, discharge them to natural hydrologic cycle directly will do extensive damage to aquatic ecosystems (Lefebvre \& Moletta 2006). Under these circumstances, investigating the processing technology becomes the key to solve the hypersaline wastewater pollution.

The existing treatment methods of saline wastewater principally include physical, chemical and biological technologies. Physicochemical methods (membrane filtration, electro-oxidation and ion exchange etc.) usually generate problems like high cost and complex management. Many researchers have focused on biological processes due to their high efficiency and low cost. At present, the biological treatment is mainly conducted in the sequencing batch reactor (SBR), fixed-bed reactor, upflow anaerobic packed bed reactor, etc. However, high salinity will prevent common microorganisms from maintaining osmotic pressure balance, giving rise to bacterial plasmolysis, finally leading to the failure of bio-treatment. On the other hand, the high content of total dissolved organics in the saline wastewater will easily bring about sludge bulking, leading to increasing sludge volume index values and bad sludge settling property (Wang et al. 2015).

The discovery of halophilic bacteria provides a feasible solution for biological treatment of high salinity wastewater. Previous studies have shown that using halophilic bacteria to deal with brine wastewater is not only feasible but also can improve treatment performance in multiple kinds of bioreactors. The presence of a variety of heterotrophic halophilic bacteria can achieve efficient removal of organic matter in saline wastewater. However, how to effectively enrich halophile bacteria is a current issue of applying this technology. SBBR possesses both advantages of SBR and biofilm reactor, with high solids retention, the possibility of appropriate process control and strong resistance to 
the loading fluctuation (Helness \& Ødegaard 2001). By comparing the existing studies, the SBBR system required less time than SBR to start-up when operated at the same salinity.

All degradation and metabolic processes of microorganisms rely on enzyme-catalysed reactions, which can be markedly affected by temperature (Adams et al. 2010). Applying bio-technology to hypersaline wastewater treatment plant always struggles with seasonal changes. Especially when temperature plummets or winter comes, the low temperature can restrain the efficiency of the microbial enzyme systems, bringing about a deterioration of bio-treatment performance. However, the studies on the hypersaline wastewater treatment were primarily limited to the influence of several factors, like different reactor configuration, salinity and organic loading rate. Moreover, most studies about the effect of temperature on hypersaline wastewater bio-technologies focused on anaerobic biological treatments. Therefore, research of aerobic bio-technology removing COD in hypersaline wastewater at low temperature is important, especially using industrial wastewater instead of synthetic wastewater in pilot-scale water treatment.

This study was conducted to examine the performance of a set of pilot-scale SBBRs with different organic loading rates (OLR) treating 70 g. $\mathrm{L}^{-1} \mathrm{NaCl}$ hypersaline wastewater. The effect of temperature downshifts on COD removal efficiency was investigated. PCR-DGGE was used to reveal the microbial community succession along with temperature decreasing. This study aims to demonstrate if the SBBR can deal with temperature shocks and oscillations when it is applied to treat hypersaline wastewater and to understand how microbial communities maintained their degradation ability at the low-temperature condition, providing useful information related to hypersaline wastewater treatment for future studies.

\section{MATERIALS AND METHODS}

Study site: The pilot-scale SBBRs used in the experiment were operated at the Fuling mustard factory. Fuling mustard factory is the pillar industry of the Three Gorges reservoir area in western China. Because a huge amount of sodium chloride was used during the production of the pickled mustard tuber, the factory produces hypersaline wastewater and needs to be pretreated before it is drained into a municipal sewage treatment system. The characteristics of the influent are presented in Table 1.

Description of pilot-scale SBBRs: The pilot-scale system (Fig. 1) consisted of three parallel SBBRs (S1, S2 and $\mathrm{S} 3$ ), each reactor with a total effective volume of $3.57 \mathrm{~m}^{3}$ and dimensions of $3.0 \times 0.7 \times 1.7 \mathrm{~m}^{3}(\mathrm{~L} \times \mathrm{W} \times \mathrm{H})$. Poly-
Table 1: Characteristics of hypersaline pickled mustard tuber wastewater.

\begin{tabular}{|c|c|}
\hline Parameter & Value $($ mean $\pm S D)$ \\
\hline Salinity $\left(\mathrm{g} \cdot \mathrm{L}^{-1} \mathrm{NaCl}\right)$ & $70 \pm 6$ \\
\hline $\mathrm{NO}_{3}{ }^{-}-\mathrm{N}\left(\mathrm{mg} \cdot \mathrm{L}^{-1}\right)$ & $42 \pm 3$ \\
\hline $\operatorname{COD}\left(\mathrm{mg} \cdot \mathrm{L}^{-1}\right)$ & $8243 \pm 502$ \\
\hline $\mathrm{BOD}_{5}\left(\mathrm{mg} \cdot \mathrm{L}^{-1}\right)$ & $4512 \pm 612$ \\
\hline $\mathrm{pH}$ & $5.5 \pm 0.5$ \\
\hline
\end{tabular}

urethane suspension spherical fillers were submerged in the reactor and their packing ratios were about 53\%. Air was provided through microporous aerators equipped in the bottom of reactors to maintain the DO values between 5.7-6.3 mg. $\mathrm{L}^{-1}$. The inflow was stored in a feed tank and supplied to the bioreactors by an influent pump. The variation of temperature controlled by a constant temperature room. SBBRs were run in a $24 \mathrm{~h}$ cycle, consisting of $0.25 \mathrm{~h}$ filling, $23.5 \mathrm{~h}$ aerobic reaction, and $0.25 \mathrm{~h}$ drawing.

Experimental procedure: The reactors were inoculated with dewatered activated sludge taken from a sewage wastewater treatment plant (WWTP) in Chongqing, China. In the first week, a visible thick biofilm was obtained by inoculation in salt-free condition and then began the formal operation. During operation, the OLR of the S1, S2 and $\mathrm{S} 3$ were controlled at $1.03 \pm 0.07,2.03 \pm 0.13$ and 3.07 $\pm 0.15 \mathrm{~kg} \mathrm{COD} \mathrm{m}^{-3} \mathrm{~d}^{-1}$ (they would be represented by an

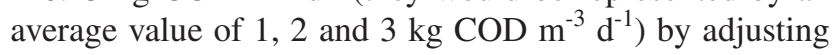
the volumetric exchange ratio (VER). The experimentation concluded three phases (phase I, II and III), each of which was characterized by different temperatures. During phase I, the water temperature was kept at $30 \pm 1{ }^{\circ} \mathrm{C}$. As the 70 g. $\mathrm{L}^{-1} \mathrm{NaCl}$ influent was fed in, the salinity of the reactor gradually increased. While the salinities in the reactors were above 65 g.L $\mathrm{L}^{-1} \mathrm{NaCl}$ and the obtained COD removal efficiencies stably exceeded $60 \%$, considered the reactors had been successfully started. Moved into the next phase after the reactors had been operated in stable condition at $30 \pm$ $1^{\circ} \mathrm{C}$. In phase II, the temperature was adjusted to $20 \pm 2{ }^{\circ} \mathrm{C}$, operated SBBRs until the effluents were steady and entered

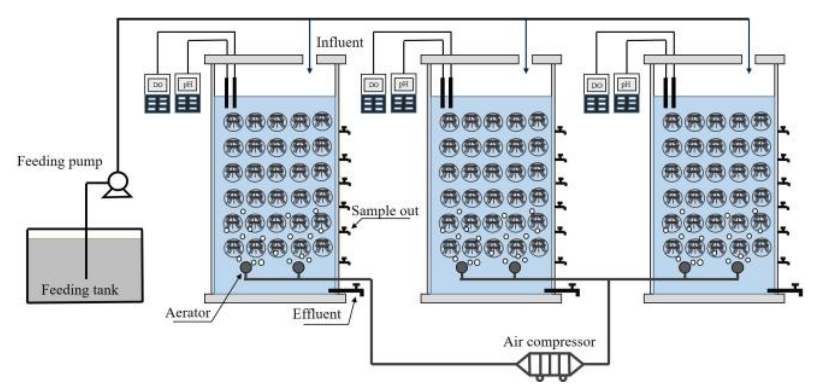

Fig.1: Schematic of the pilot SBBRs. 
into phase III. In phase III, temperature was declined to $10 \pm$ $1^{\circ} \mathrm{C}$, such a status further kept until the end of the experiment. During each stable period of phase I, II and III, the stability of SBBRs facing temperature oscillation was investigated. The temperature was controlled to fluctuate in the range of $30 \pm 4^{\circ} \mathrm{C}, 20 \pm 4^{\circ} \mathrm{C}$ and $10 \pm 4^{\circ} \mathrm{C}$ in phase I-III. Each stable effluent period lasted at least 30 days. Meanwhile, the COD of influent and effluent was measured every day.

Analytical methods: Temperature, dissolved oxygen (DO) and $\mathrm{pH}$ were measured by $\mathrm{DO}$ and $\mathrm{pH}$ meter $(\mathrm{HACH}, \mathrm{HQ} 30 \mathrm{~d}$, USA). COD and $\mathrm{BOD}_{5}$ were analysed according to Standard Methods (APHA 2005).

DNA extraction: DNA of the inoculated sludge and biomass samples, which were collected from the stable effluent conditions of S3 during phase I, II and III, were extracted by using the method described by Miller et al. (1999). The extractions were checked by $0.8 \%$ agarose gel electrophoresis and stored at $-20^{\circ} \mathrm{C}$ for PCR amplification.

PCR amplification and DGGE: The highly variable V3 region of the bacterial $16 \mathrm{~S}$ rRNA gene was amplified by a PCR universal primer pair 357F-GC (5'-GC-clamp-CCTACGGGAGGCAGCAG-3') and 518R (5'-ATTACCGCGGCTGCTGG-3') with a GC clamp (CGCCCGCCGCGCGCGGCGGGCGGGGCGG GGGCACGGGGGG) attached to the forward primer (Muyzer et al. 1993). The procedure of the amplification was as follows: 1 cycle of initial denaturation at $94^{\circ} \mathrm{C}$ for $5 \mathrm{~min}$; then 30 cycles of denaturation at $94^{\circ} \mathrm{C}$ for $45 \mathrm{~s}$, annealing at $60^{\circ} \mathrm{C}$ for $45 \mathrm{~s}$, and extension at $72^{\circ} \mathrm{C}$ for $90 \mathrm{~s}$. After that, 1 cycle of the final extension was set at $72^{\circ} \mathrm{C}$ for $10 \mathrm{~min}$. PCR products were analysed by $2 \%$ agarose gel electrophoresis.

The expected sizes of the amplified fragments were 230 bp. The Dcode Universal Mutation Detection System (Bio-Rad, USA) was used to perform DGGE analysis. The PCR products were run on an $8 \%$ polyacrylamide gel with denaturing ranges from $37.5-55 \%$. The temperature was set to $60^{\circ} \mathrm{C}$ simultaneously, DGGE at $200 \mathrm{~V}$ was run for $10 \mathrm{~min}$, and then $80 \mathrm{~V}$ for $900 \mathrm{~min}$. After electrophoresis, the gels were stained with ethidium bromide solution for 25 min before placing them under the Bio-Rad Versa Doc for observation and photographed. The images were processed with Bio-Rad Quantity One Software Version 4.6.2.

DNA sequencing and the phylogenetic tree: The desired bands in DGGE gels were cut off to study the effective strains. Each gel fragment was resolved in $50 \mu \mathrm{L}$ sterile deionized water and kept overnight at $4^{\circ} \mathrm{C}$. The DNA bands from the gel fragment were excised and PCR amplifications performed as above except using the primer without a GC clamp. The 16S rRNA gene fragment clones were sequenced by the BGI Company (BGI, Shenzhen, China). The results were compared with the GenBank database using the $\mathrm{Nu}$ cleotide Blast. A neighbour-joining algorithm-based phylogenetic tree was constructed using MEGA 5.0 software and bootstrap analyses for 1000 replicates were performed. The Dice-coefficients were analysed by Quantitation Software Version 4.6.2 software (Bio-Rad Laboratories, USA) to study the similarities in band patterns.

\section{RESULTS AND DISCUSSION}

Reactor performance: The COD removal efficiencies of the 1, 2 and $3 \mathrm{~kg} \mathrm{COD} \mathrm{m}^{-3} \mathrm{~d}^{-1}$ SBBR (S1, S2 and S3) during the operation are shown in Fig. 2. During phase I, as the salinity increasing, COD removal efficiency in all the three reactors decreased. This adverse effect had lasted for 3-5 days before it started ameliorating. This phenomenon happened because the gradual increasing salinity caused plenty of microorganisms, which came from the inoculated sludge, could not adapt to high salinity and were eliminated (Chen et al. 2016). The salinities of S1, S2 and S3 all were increased to $67 \pm 2 \mathrm{~g} . \mathrm{L}^{-1} \mathrm{NaCl}$ during the initial 17 days, and the removal

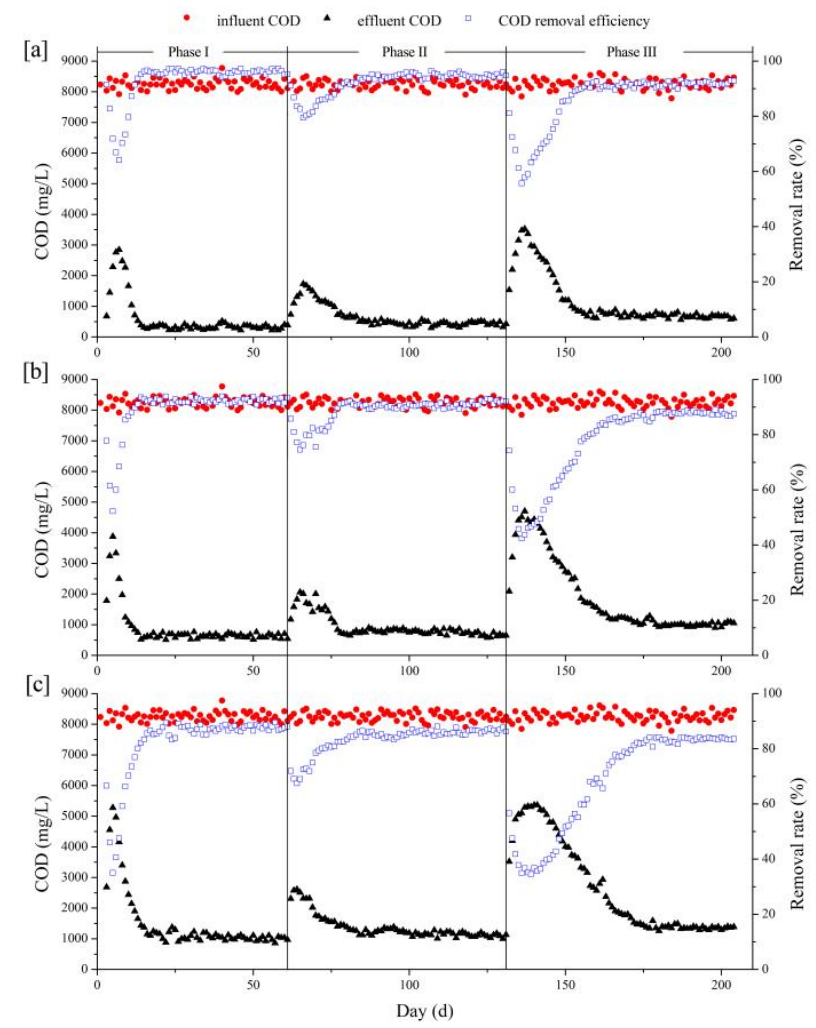

Fig. 2: The variations of COD concentrations in the influent and effluent of three SBBRs: $1 \mathrm{~kg}$ COD m$^{-3} \mathrm{~d}^{-1}$ SBBR reactor, [a]; $2 \mathrm{~kg} \mathrm{COD} \mathrm{m}^{-3} \mathrm{~d}^{-1}$ SBBR reactor, [b]; $3 \mathrm{~kg}$ COD m${ }^{-3} \mathrm{~d}^{-1}$ SBBR reactor, [c]. 
rates of COD were steadily over $85 \%$, which meant three reactors had successfully started up under $30^{\circ} \mathrm{C}$. The rapid lifting of salinity often has a severe impact on the system's performance, leading to rapid deterioration and challenging restoration. In the study of Uygur \& Kargi (2004), using SBR treating synthetic wastewater, the COD removal efficiency decreased from $96 \%$ to $32 \%$ as salt content increased from $0 \%$ to $6 \%$. The result of this study indicates that SBBR owns a better resistance to the increasing salinity and can start-up in a short time when it is applied to treat hypersaline wastewater.

Under $30 \pm 4{ }^{\circ} \mathrm{C}$ condition, the effluent COD of S1, S2 and S3 finally remained stable at $325 \pm 90 \mathrm{mg} . \mathrm{L}^{-1}, 625 \pm 100$ mg. $\mathrm{L}^{-1}$ and $1000 \pm 120 \mathrm{mg} . \mathrm{L}^{-1}$. The corresponding average removal efficiencies approached to $96.07 \%, 92.42 \%$ and $87.91 \%$, respectively. When the temperature dropped to 20 $\pm 2^{\circ} \mathrm{C}$, COD removal rates declined slightly at the beginning. After 15-21 days of acclimation, effluent COD of S1, S2 and S3 finally remained stable at $425 \pm 100 \mathrm{mg} . \mathrm{L}^{-1}, 775 \pm 80$ $\mathrm{mg} . \mathrm{L}^{-1}$ and $1175 \pm 120 \mathrm{mg} . \mathrm{L}^{-1}$. In phase II, the average removal efficiencies recovered to $94.85 \%, 90.62 \%$ and $85.78 \%$, respectively. In phase III, as the temperature was further declined to $10 \pm 1^{\circ} \mathrm{C}$, the COD removal efficiency decreased significantly. The domestication time S1, S2 and S3 used was much longer than they had spent during phase II. After 31, 47, 41 days, effluent COD of S1, S2 and S3 became steadily at $690 \pm 100 \mathrm{mg} . \mathrm{L}^{-1}, 1004 \pm 70 \mathrm{mg} . \mathrm{L}^{-1}$ and $1375 \pm 100 \mathrm{mg} . \mathrm{L}^{-1}$, and the average removal efficiencies were $91.6 \%, 87.84 \%$ and $83.34 \%$, respectively.

The COD removal efficiency was higher in low OLR reactor. However, S3 still got a COD removal rate of more than $91 \%$ at $30^{\circ} \mathrm{C}$. In this study, using SBBR to treat hypersaline industrial wastewater with high organic content was feasible. During the temperature decreasing from $30^{\circ} \mathrm{C}$ to $10^{\circ} \mathrm{C}$, more time was needed for reactors to regain stable performance when they adapted to $10^{\circ} \mathrm{C}$ conditions. It means low temperature gave a strong shock for SBBR. However, after S1, S2 and S3 had adapted to the declined temperature, a certain fluctuation of temperature did not bring about performance undulated. Although three SBBRs were subjected to low temperature, COD was effectively removed at $10^{\circ} \mathrm{C}$ with the average efficiency above $83 \%$. The results were in line with the former studies, despite the fact that the COD removal efficiency was inhibited less seriously in this study than those reported at a similar level of temperature downshift. Li et al. (2012) observed that the COD removal efficiencies of a hybrid bioreactor at $25^{\circ} \mathrm{C}$ and $10^{\circ} \mathrm{C}$ were $94.78 \%$ and $66.27 \%$, respectively. Jia et al. (2012) used an SBR to treat slaughterhouse wastewater, and the result showed that COD removal efficiencies were about 78\%, 92\% and $96 \%$ at $10^{\circ} \mathrm{C}, 20^{\circ} \mathrm{C}$ and $30^{\circ} \mathrm{C}$. This research indicates that SBBR may own a better resistance to temperature decline and can successfully deal with temperature change.

Cycle profile: To understand more details about the process, 24 h cycle profiles of S1 (Fig. 3a), S2 (Fig. 3b) and S3 (Fig. $3 \mathrm{c}$ ) were analysed at $10^{\circ} \mathrm{C}, 20^{\circ} \mathrm{C}$ and $30^{\circ} \mathrm{C}$, respectively. The conversion rates of COD were distinctly higher in S3. Degradation rates were greatly affected by organic loading. With higher OLR, more nutrients were available for microorganism propagation and growth, leading to a larger population, and COD conversion happened faster.

In the same reactor, the COD degradation rates of $10^{\circ} \mathrm{C}$, $20^{\circ} \mathrm{C}$ and $30^{\circ} \mathrm{C}$ were not significantly different from each other. Biofilm systems had stronger resistance to temperature changes compared to suspended sludge systems (Odegaard 2006). In the biofilm system, microorganisms were attached
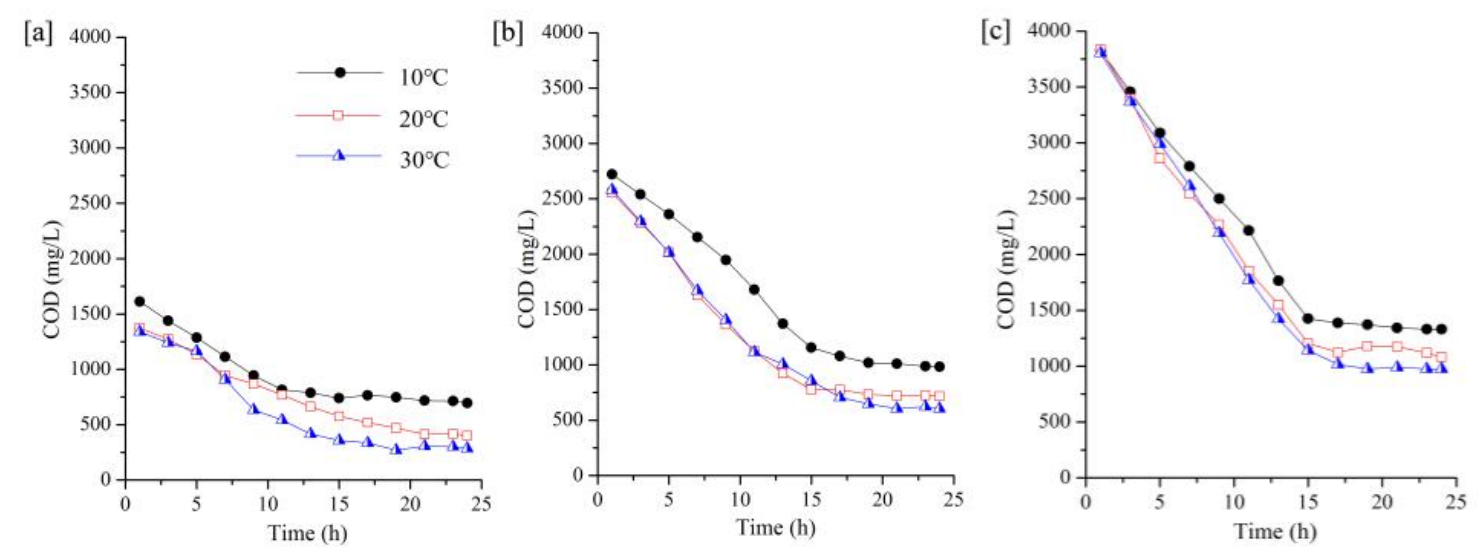

Fig. 3: The COD degradation cycle profile of three SBBRs: $1 \mathrm{~kg} \mathrm{COD} \mathrm{m}^{-3} \mathrm{~d}^{-1} \mathrm{SBBR}$ reactor, [a]; $2 \mathrm{~kg} \mathrm{COD} \mathrm{m}^{-3} \mathrm{~d}^{-1} \mathrm{SBBR}$ reactor, [b]; $3 \mathrm{~kg} \mathrm{COD} \mathrm{m} \mathrm{d}^{-1}$ SBBR reactor, [c]. 
growth, and more kinds of bacteria were reserved in the system, which was conducive to the growth of microorganisms which possessed the different temperature competitiveness. Combined with the DGGE analysis, when temperature downshifted to $10^{\circ} \mathrm{C}$, species which could adapt to a wider range of temperature thrived and were responsible for COD removal. As a result, the system maintained a stable performance.

Bacterial community diversity: The diversities of the microbial community of samples were analysed by PCRDGGE (Fig. 4). The banding patterns showed that microbial community structures of $3 \mathrm{~kg}$ COD m$~^{-3} \mathrm{~d}^{-1}$ SBBR under different temperature (Lane 1, 2 and 3) changed significantly from inoculated sludge (Lane 0 ). That suggested majority of microorganisms in seed sludge could not survive in 70 g.L${ }^{1} \mathrm{NaCl}$ environment, few halophilic microorganisms from both seed sludge and mustard tuber wastewater gradually multiplied and became dominant populations (Chen et al. 2016).

The total number of bands of Lane 1, 2, 3 (30, 20 and $10^{\circ} \mathrm{C}$ ) did not greatly vary from each other. However, microbial structure and population distribution changed significantly after S3 operated at low temperature. The Dice coefficients of lane 3 with Lane 1 and Lane 2 were $46.1 \%$ and $55.2 \%$. The results indicate that the temperature has a notable effect on the microbial community structure. The same result was reported by Moura et al. (2009), revealing bacterial communities of an aerated lagoon could be grouped
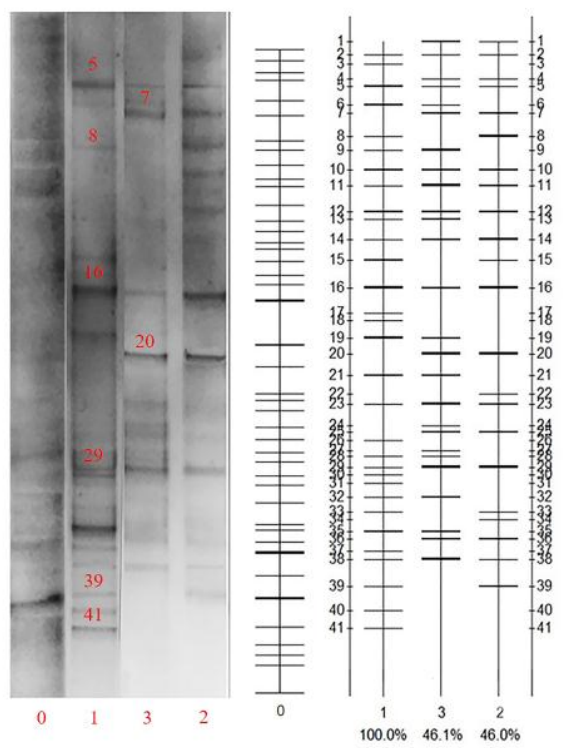

Fig. 4: The microbial communities of samples: inoculated sludge, Lane 0 ; S3 biofilm sample at $30^{\circ} \mathrm{C}$, Lane 1; S3 biofilm sample at $20^{\circ} \mathrm{C}$, Lane 2; $\mathrm{S} 3$ biofilm sample at $10^{\circ} \mathrm{C}$, Lane 3 . The left one was the DGGE patterns and the right one was the analysis result of the DGGE pattern by Quantitation Software Version 4.6.2. into three clusters: fall/winter, spring and summer cluster by following the temperature change.

Bacterial community cluster analysis: After excising from the gel, 8 prominent bands were sequenced and successfully identified. The sequencing results are given in Table 2 and a phylogenetic tree was constructed (Fig. 5).

Compared to $30^{\circ} \mathrm{C}$ and $20^{\circ} \mathrm{C}$ samples (Lane 1 and Lane 2 ), the abundance of bacterial population represented by band 7, 20, 29 increased at $10^{\circ} \mathrm{C}$ (Lane 3). Band 7 and 20 only appeared at phase 2 and $3\left(20^{\circ} \mathrm{C}\right.$ and $\left.10^{\circ} \mathrm{C}\right)$, were related to Thalassolituus oleivorans, Halotalea alkalilenta. Thalassolituus oleivorans is an aerobic heterotrophic, hydrocarbon-utilizing bacteria, motile using one to four polar flagella, growth occurs at $0.5-5.7 \% \mathrm{NaCl}$ at $4-30^{\circ} \mathrm{C}$, numerous isolates were obtained from the polar coastal area of Russia (Yakimov et al. 2004, Yakimov et al. 2007). Several studies used it to bio-remediate oil-polluted seawater (Hassanshahian et al. 2014a, Hassanshahian et al. 2014b). Halotalea alkalilenta, which is an aerobe heterotrophic bacteria tolerates up to $15 \% \mathrm{NaCl}$, motile by peritrichous flagella, and the temperature range for growth is $5-45^{\circ} \mathrm{C}$ (Ntougias et al. 2007). Band 29 was affiliated with Kangiella koreensis and occurred in S3 among all phases despite how the temperature had changed. Kangiella koreensis is a facultative anaerobic bacterium, can reduce nitrate to nitrogen gas under anaerobic conditions, non-motile. Growth occurs between $4-43^{\circ} \mathrm{C}$ and cannot grow without $\mathrm{NaCl}$ or in the presence of more than $13 \% \mathrm{NaCl}$ (Yoon et al. 2012). Chun et al. (2012) had detected this strain in a full-scale seawater desalination process operated in a cartridge filter.

Band 5 and 16 were classified as Marinimicrobium koreense and Zobellella taiwanensis, respectively. They persistently existed during the whole cultivation process, but the bacterial population abundance decreased when the temperature dropped to $10^{\circ} \mathrm{C}$. Marinimicrobium koreense is an aerobic chemoheterotroph bacterium, grows in the range $0-15 \%$ salinity (Lim et al. 2006). Zobellella taiwanensis is a facultative anaerobic bacterium which grows in $0-14 \% \mathrm{NaCl}$ and can achieve anaerobic growth by undertaking either denitrification or fermentation (Lin \& Shieh 2006). Both bacteria mentioned above grow at $10-45^{\circ} \mathrm{C}$ and frequently possess a single polar flagellum.

Band 8 and 39 were separately affiliated to Simiduia agarivorans and Nitrincola lacisaponensis, respectively, appeared only at $30^{\circ} \mathrm{C}$ and $20^{\circ} \mathrm{C}$, entirely disappeared at $10^{\circ} \mathrm{C}$. Simiduia agarivorans is a mesophilic halophilic bacterium, can grow in the range of $0.5-7 \% \mathrm{NaCl}, 15-40^{\circ} \mathrm{C}$. Nearly all cells are non-motile. It is capable of anaerobic growth by reducing nitrate to nitrite (Shieh et al. 2008). As a halotoler- 
Table 2: Sequence analysis of bands excised from DGGE gels.

\begin{tabular}{|llll|}
\hline Band & Closest relative & Similarity (\%) & Accession No. \\
\hline 5 & Marinimicrobium koreense & 100 & NR_043222.1 \\
7 & Thalassolituus oleivorans & 99 & NR_028972.1 \\
8 & Simiduia agarivorans & 100 & NR_044318.1 \\
16 & Zobellella taiwanensis & 94 & NR_043630.1 \\
20 & Halotalea alkalilenta & 100 & NR_043806.1 \\
29 & Kangiella koreensis & 98 & NR_027574.1 \\
39 & Nitrincola lacisaponensis & 100 & NR_042984.1 \\
41 & Nitratifractor salsuginis & 100 & NR_041024.1 \\
\hline
\end{tabular}

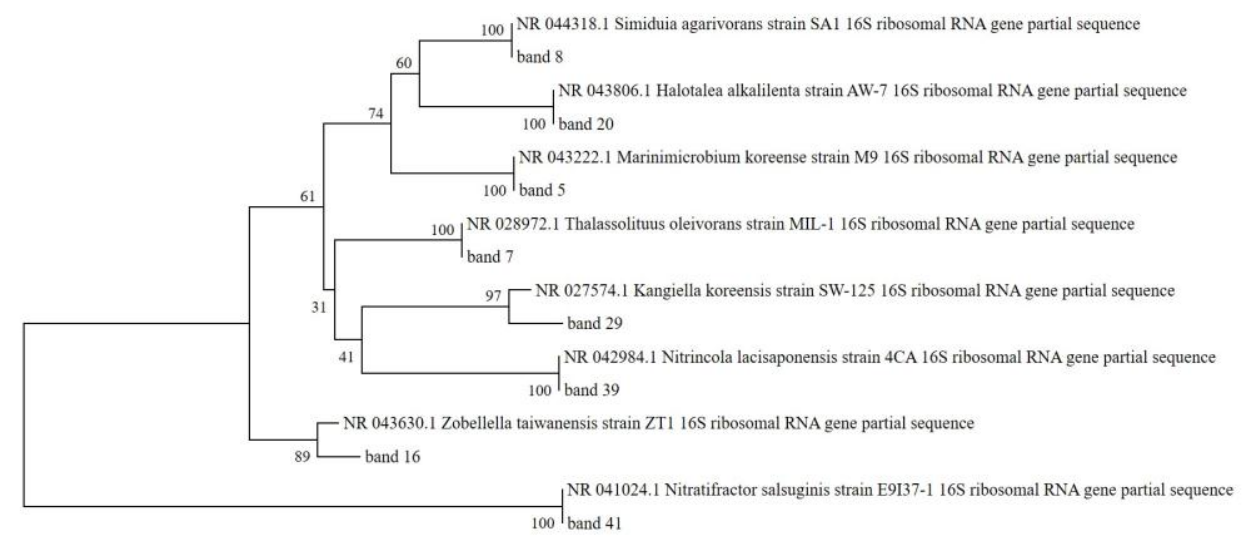

$\stackrel{\longmapsto}{\longmapsto_{02}}$

Fig. 5: Phylogenetic tree constructed by MEGA 5.0 software, and the sequences derived from DGGE patterns of the system.

ant and heterotrophic bacterium, Nitrincola lacisaponensis utilizes $\mathrm{NO}_{2}$ and $\mathrm{O}_{2}$ as electron acceptors. Cells can use single flagellum to move and can grow at $15-40^{\circ} \mathrm{C}$. Band 41 was related to Nitratifractor salsuginis, vanished after the temperature dropped from $30^{\circ} \mathrm{C}$. Nitratifractor salsuginis is a strictly chemoautotrophic denitrifying bacterium and grows at $28-40^{\circ} \mathrm{C}$ (Nakagawa et al. 2005).

Comparing the above results, bacteria which could adapt to a wide range of temperature gradually became dominant populations at $10^{\circ} \mathrm{C}$. The presence of aerobic, anoxic and anaerobic microenvironments in biofilms provide living conditions for the facultative anaerobic bacterium. The study of Herald \& Zottola (1988) showed that cells were shown to have single flagellum at 35 but several flagella at $10{ }^{\circ} \mathrm{C}$ which indicated when the temperature dropped, the bacteria with stronger adhesion were tended to be more competitive. In this research, under low temperature condition, the predominant strains tend to possess several flagella while bacteria with single flagella were decreasing. This phenomenon is consistent with the above conclusion.

The suitable temperature, salt tolerance range, and other characteristics of the identified bacteria were consistent with the system parameters. It is considered that the microbial community dominated by halophilic bacteria had been successfully domesticated in SBBR, achieving a high organic matter removal efficiency at a different temperature. The declined temperature did not significantly reduce microbial diversity in the reactor, however, halophilic bacteria with a broad range of growth temperature gradually predominate because of the gradual succession.

\section{CONCLUSION}

In this study, pilot-scale SBBRs were quickly started up treating 70 g. $\mathrm{L}^{-1} \mathrm{NaCl}$ pickled mustard tuber wastewater. The effect of temperature downshifts on system treatment efficiencies and microbial population succession were investigated. Under 70 g. $\mathrm{L}^{-1} \mathrm{NaCl}$ condition, high $\mathrm{COD}$ removal efficiencies were obtained at $30^{\circ} \mathrm{C}, 20^{\circ} \mathrm{C}$ and $10^{\circ} \mathrm{C}$ in SBBRs with different OLR. The decrease in temperature caused a population succession. At $10^{\circ} \mathrm{C}$, halophilic bacteria with better temperature resistance and stronger adhesion became dominant species, which were Thalassolituus oleivorans, Halotalea alkalilenta, Kangiella koreensis, Marinimicrobium koreense and Zobellella taiwanensis. 
This study demonstrates that SBBR shows robustness to temperature downshifts and fluctuation when treating hypersaline industrial wastewater.

\section{REFERENCES}

Adams, H.E., Crump, B.C. and Kling, G.W. 2010. Temperature controls on aquatic bacterial production and community dynamics in arctic lakes and streams. Environ. Microbiol., 12(5): 1319-33.

APHA 2005. Standard Methods for the Examination of Water and Wastewater, 21st Edn. American Public Health Association/American Water Works Association/Water Environment Federation, Washington DC.

Chen, J., Yi, H., Wang, Y., Gong, B., Jian, Z. and Qing, X. 2016. Start-up and microbial communities of a simultaneous nitrogen removal system for high salinity and high nitrogen organic wastewater via heterotrophic nitrification. Bioresource Technology, 216: 196-202.

Chun, Y., Ha, P.T., Powell, L., Lee, J., Kim, D., Choi, D., Lovitt, R.W., Kim, I.S., Mitra, S.S. and Chang, I.S. 2012. Exploring microbial communities and differences of cartridge filters (CFs) and reverse osmosis (RO) membranes for seawater desalination processes. Desalination, 298(29): 85-92.

Hassanshahian, M., Emtiazi, G., Caruso, G. and Cappello, S. 2014a. Bioremediation (bioaugmentation/biostimulation) trials of oil polluted seawater: A mesocosm simulation study. Marine Environmental Research, 95(4): 28.

Hassanshahian, M., Yakimov, M.M., Denaro, R., Genovese, M. and Cappello, S. 2014b. Using Real-time PCR to assess changes in the crude oil degrading microbial community in contaminated seawater mesocosms. International Biodeterioration \& Biodegradation, 93(93): 241-248.

Helness, H. and Ødegaard, H. 2001. Biological phosphorus and nitrogen removal in a sequencing batch moving bed biofilm reactor. Water Science and Technology, 43(1): 233.

Herald, P.J. and Zottola, E.A. 1988. Attachment of Listeria monocytogenes to stainless steel surfaces at various temperatures and $\mathrm{pH}$ values. Journal of Food Science, 53(5): 1549-1562.

Jia, Y., Gao, C., Zhang, L. and Jiang, G. 2012. Effects of pre-fermentation and influent temperature on the removal efficiency of COD, $\mathrm{NH}_{4}{ }^{+}-\mathrm{N}$ and $\mathrm{PO}_{4}{ }^{3-}-\mathrm{P}$ in slaughterhouse wastewater by Using SBR. Energy Procedia, 16(16): 1964-1971.

Lefebvre, O. and Moletta, R. 2006. Treatment of organic pollution in industrial saline wastewater: a literature review. Water. Res., 40(20): 3671-82.

Lefebvre, O., Quentin, S., Torrijos, M., Godon, J.J., Delgenes, J.P. and Moletta, R. 2007. Impact of increasing $\mathrm{NaCl}$ concentrations on the performance and community composition of two anaerobic reactors. Appl. Microbiol. Biotechnol., 75(1): 61-69.

Li, T., Bo, L., Fan, Y., Zhang, S., Wu, Y. and Yang, L. 2012. Comparison of the removal of COD by a hybrid bioreactor at low and room temperature and the associated microbial characteristics. Bioresource Technology, 108(3): 28.

Lim, J.M., Jeon, C.O., Lee, J.C., Song, S.M., Kim, K.Y. and Kim, C.J. 2006. Marinimicrobium koreense gen. nov., sp. nov. and Marinimicrobium agarilyticum sp. nov., novel moderately halotolerant bacteria isolated from tidal flat sediment in Korea. International Journal of Systematic \& Evolutionary Microbiology, 56(Pt 3): 653.

Lin, Y.T. and Shieh, W.Y. 2006. Zobellella denitrificans gen. nov., sp. nov. and Zobellella taiwanensis sp. nov., denitrifying bacteria capable of fermentative metabolism. International Journal of Systematic \& Evolutionary Microbiology, 56(6): 1209-1215.

Miller, D.N., Bryant, J.E., Madsen, E.L. and Ghiorse, W.C. 1999. Evaluation and optimization of DNA extraction and purification procedures for soil and sediment samples. Applied \& Environmental Microbiology, 65(11): 4715

Moura, A., Tacão, M., Henriques, I., Dias, J., Ferreira, P. and Correia, A. 2009. Characterization of bacterial diversity in two aerated lagoons of a wastewater treatment plant using PCR-DGGE analysis. Microbiological Research, 164(5): 560-569.

Muyzer, G., Waal, E.C.D. and Uitterlinden, A.G. 1993. Profiling of complex microbial populations by denaturing gradient gel electrophoresis analysis of polymerase chain reaction-amplified genes coding for $16 \mathrm{~S}$ rRNA. Applied \& Environmental Microbiology, 59(3): 695.

Nakagawa, S., Takai, K., Inagaki, F., Horikoshi, K. and Sako, Y. 2005. Nitratiruptor tergarcus gen. nov., sp. nov. and Nitratifractor salsuginis gen. nov., sp. nov., nitrate-reducing chemolithoautotrophs of the epsilon-Proteobacteria isolated from a deep-sea hydrothermal system in the Mid-Okinawa Trough. Int. J. Syst. Evol. Microbiol., 55(Pt 2): 925-933.

Ntougias, S., Zervakis, G.I. and Fasseas, C. 2007. Halotalea alkalilenta gen. nov., sp. nov., a novel osmotolerant and alkali tolerant bacterium from alkaline olive mill wastes, and emended description of the family Halomonadaceae Franzmann et al. 1989, emend. Dobson and Franzmann 1996. International Journal of Systematic \& Evolutionary Microbiology, 57(Pt 9): 1975-1983.

Odegaard, H. 2006. Innovations in wastewater treatment: the moving bed biofilm process. Water Science \& Technology, 53(9): 17.

Shieh, W.Y., Liu, T.Y., Lin, S.Y., Jean, W.D. and Chen, J.S. 2008. Simiduia agarivorans gen. nov., sp. nov., a marine, agarolytic bacterium isolated from shallow coastal water from Keelung, Taiwan. International Journal of Systematic \& Evolutionary Microbiology, 58(Pt 4): 895.

Uygur, A. and Kargi, F. 2004. Biological nutrient removal from pre-treated landfill leachate in a sequencing batch reactor. J. Environ. Manage., 71(1): 9-14.

Wang, Z., Gao, M., She, Z., Wang, S., Jin, C., Zhao, Y., Yang, S. and Guo, L. 2015. Effects of salinity on performance, extracellular polymeric substances and microbial community of an aerobic granular sequencing batch reactor. Separation and Purification Technology, 144: 223-231.

Yakimov, M.M., Giuliano, L., Denaro, R., Crisafi, E., Chernikova, T.N., Abraham, W.R., Luensdorf, H., Timmis, K.N. and Golyshin, P.N. 2004. Thalassolituus oleivorans gen. nov., sp. nov., a novel marine bacterium that obligately utilizes hydrocarbons. International Journal of Systematic \& Evolutionary Microbiology, 54(1): 141-148.

Yakimov, M.M., Timmis, K.N. and Golyshin, P.N. 2007. Obligate oildegrading marine bacteria. Current Opinions in Biotechnology, 18(3): 257-266.

Yoon, J.H., Kang, S.J., Lee, S.Y., Lee, J.S. and Oh, T.K. 2012. Kangiella geojedonensis sp. nov., isolated from seawater. International Journal of Systematic \& Evolutionary Microbiology, 62(Pt 3): 511. 